\title{
SOEP
}

SOEPpapers

on Multidisciplinary Panel Data Research
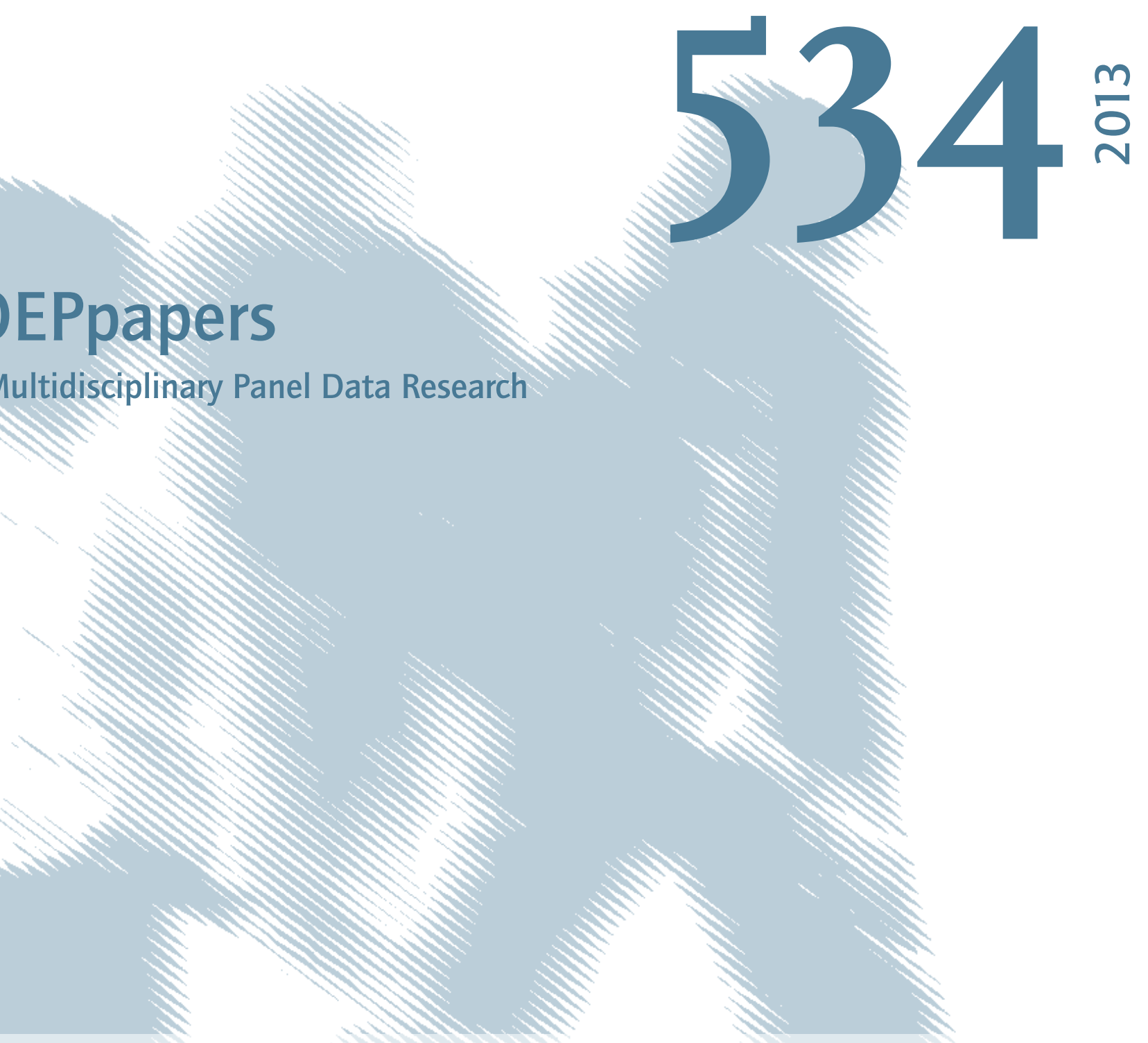

\section{The Effects of $9 / 11$ on Attitudes Toward Immigration and the Moderating Role of Education}




\section{SOEPpapers on Multidisciplinary Panel Data Research}

at DIW Berlin

This series presents research findings based either directly on data from the German SocioEconomic Panel Study (SOEP) or using SOEP data as part of an internationally comparable data set (e.g. CNEF, ECHP, LIS, LWS, CHER/PACO). SOEP is a truly multidisciplinary household panel study covering a wide range of social and behavioral sciences: economics, sociology, psychology, survey methodology, econometrics and applied statistics, educational science, political science, public health, behavioral genetics, demography, geography, and sport science.

The decision to publish a submission in SOEPpapers is made by a board of editors chosen by the DIW Berlin to represent the wide range of disciplines covered by SOEP. There is no external referee process and papers are either accepted or rejected without revision. Papers appear in this series as works in progress and may also appear elsewhere. They often represent preliminary studies and are circulated to encourage discussion. Citation of such a paper should account for its provisional character. A revised version may be requested from the author directly.

Any opinions expressed in this series are those of the author(s) and not those of DIW Berlin. Research disseminated by DIW Berlin may include views on public policy issues, but the institute itself takes no institutional policy positions.

The SOEPpapers are available at

http://www.diw.de/soeppapers

\section{Editors:}

Jürgen Schupp (Sociology, Vice Dean DIW Graduate Center)

Gert G. Wagner (Social Sciences)

Conchita D'Ambrosio (Public Economics)

Denis Gerstorf (Psychology, DIW Research Director)

Elke Holst (Gender Studies, DIW Research Director)

Frauke Kreuter (Survey Methodology, DIW Research Professor)

Martin Kroh (Political Science and Survey Methodology)

Frieder R. Lang (Psychology, DIW Research Professor)

Henning Lohmann (Sociology, DIW Research Professor)

Jörg-Peter Schräpler (Survey Methodology, DIW Research Professor)

Thomas Siedler (Empirical Economics)

C. Katharina Spieß (Empirical Economics and Educational Science)

ISSN: 1864-6689 (online)

German Socio-Economic Panel Study (SOEP)

DIW Berlin

Mohrenstrasse 58

10117 Berlin, Germany

Contact: Uta Rahmann | soeppapers@diw.de 


\title{
The Effects of 9/11 on Attitudes Toward Immigration and the Moderating Role of Education
}

\author{
Simone Schüller
}

\begin{abstract}
The major event of the 9/11 terror attacks is likely to have induced an increase in antiimmigrant and anti-foreigner sentiments, not only among US residents but also beyond US borders. Using longitudinal data from the German Socio-Economic Panel and exploiting exogenous variation in interview timing throughout 2001, I find that the terror attacks in the US caused an immediate shift of around 40 percent of one within standard deviation to more negative attitudes toward immigration and resulted in a considerable decrease in concerns over xenophobic hostility among the German population. Furthermore, in exploiting withinindividual variation this quasi-experiment provides evidence on the role of education inmoderating the negative terrorism shock.
\end{abstract}

JEL Classification: $\quad$ F22, I21, J61

Keywords: $\quad$ immigration, attitudes, education, September 11, terrorism

Corresponding author:

Simone Schüller

IZA

P.O. Box 7240

53072 Bonn

Germany

E-mail: schueller@iza.org

\footnotetext{
*Financial support from the German Research Foundation (DFG) for the project "Ethnic Diversity and Labor Market Success" in the DFG-Priority Program "Flexibility in Heterogeneous Labor Markets" is gratefully acknowledged. This paper has benefited from insightful comments by participants of the IZA Brownbag Seminar, the GSOEP Brownbag Seminar, and in particular Costanza Biavaschi, Martin Fischer, Andrew J. Oswald, Ulf Rinne, Dan-Olof Rooth and Klaus F. Zimmermann. All remaining errors are my own.
} 


\section{Introduction}

Several recent studies have examined whether the terrorist attacks in the US on September 11, 2001 (9/11) increased labor market discrimination toward certain minorities, not only in the US (e.g. Dávila and Mora, 2005; Orrenius and Zavodny, 2006; Kaushal et al., 2007; Rabby and Rodgers, 2011), but also in other countries such as Canada (Shannon, 2012), Australia (Goel, 2010), the UK (Braakmann, 2010),

Sweden Aslund and Rooth, 2005) and Germany Braakmann, 2009; Cornelissen and Jirjahn, 2012). These studies are based on two assumptions. First, that the 9/11 attacks had a direct and significant enough impact on individuals' attitudes, resulting in an increase in discriminatory behavior toward immigrants as a group or certain minorities. Second, the terrorist attacks in the US are assumed to have caused negative international spillover effects to public sentiments toward minority groups in other countries. The existing empirical literature relies on evidence from aggregate time trends that indicate, for example, dramatic increases in hate crimes against Muslims in the aftermath of the $9 / 11$ attacks, not only in the US but also beyond its borders. Overall, it is unsurprising that a large-scale terror event such as 9/11 fueled acts of anti-immigrant or anti-Muslim aggression and hostility. However, it remains to be seen whether these events caused attitude shifts among the wider society, and whether such an impact was uniform across all types of individuals. To date, no empirical study has attempted to establish a causal connection between the $9 / 11$ incident and attitude shifts in the overall population, either in the US or beyond its borders, and little is also known about heterogeneous effects.

This study offers the first empirical analysis to test the causality of the relationship between a major media event such as the 9/11 terror attacks and public immigration-related attitudes, controlling for aggregate time trends. Besides documenting whether the events of 9/11 resulted in attitudinal changes toward immigration outside the US in a European country, this analysis also contributes more generally to the literature concerned with the extent to which people's views about immigration are driven by factors other than economic self-interest. Several recent studies have consistently found a significant and positive relationship between education or skill levels among individuals and their views about immigration (e.g. Scheve and Slaughter, 2001; Mayda, 2006). While these findings have been interpreted as a reflection of labor-market dynamics, where low-skilled workers are most opposed to low-skilled immigration due to realistic fears about labor market competition, another line of scholars have questioned this interpretation. For example, Dustmann and Preston (2007) and Hainmueller and Hiscox (2007, 2010) find that a large component of the effect of education on individual attitudes toward immi- 
gration is associated with differences in cultural values and beliefs rather than with fear of labor market competition. The contribution of this paper to this strand of literature is twofold. First, utilizing the 9/11 events as an exogenous, non-economic shock, I am able to isolate non-economic drivers of immigration-related attitudes, identifying the extent to which education plays a moderating role in attitude formation in the absence of a realistic threat of economic competition. Second, exploiting intra-individual variation in attitudes over time represents an important contribution to a literature that has been exclusively based on cross-sectional comparisons to date.

Using longitudinal data from the German Socio-Economic Panel (SOEP) allows to examine the impact of the 9/11 attacks on the attitudes of German residents in a quasi-experimental setting. I exploit the fact that annual survey interviews are randomly completed throughout the year, in comparing the attitude levels of preand post-9/11 respondents in 2001, and relating these attitudes to the respective attitude levels of the same respondents one year prior. This provides approximate estimates of the causal impact of the terror attacks on the attitudes of the German population toward immigration 11 Furthermore, I examine two types of immigrationrelated attitudes - individuals' concerns over immigration and people's concerns over xenophobic hostility - presuming that the former is mainly associated with evaluations of immigration policies and perceived consequences for the host country, while the latter is more likely related to ethnic prejudice or discrimination Bauer et al., 2000; Ceobanu and Escandell, 2010).

Indeed, I find a non-negligible shift to more negative attitudes toward immigration among German residents as a result of the 9/11 terrorist attacks. At the same time, the attacks resulted in decreasing concerns over hostility toward foreigners. Moreover, I find no evidence of the 9/11 events causing similar changes in individuals' worries about overall economic development or crime in Germany, which confirms the non-economic nature of the $9 / 11$ shock on immigration-related attitudes. Hence, these results confirm the importance of cultural prejudice in driving immigration-related attitudes and emphasize that public attitude shifts can be potentially triggered by major media events such as the 9/11 attacks.

Further investigation shows that a significant 9/11 impact on attitudes toward immigration is mainly prevalent among respondents with below-average education levels, while I find no evidence of a significant attitude shift among highly educated individuals. These results are consistent with a moderating role of education in the

\footnotetext{
${ }^{1}$ Similar strategies have been used by Metcalfe et al. (2011) to analyze 9/11-effects on subjective well-being in the UK, and by Goel (2010) to investigate changes in immigrants' perceptions of racial intolerance and labor market outcomes in Australia as a consequence of 9/11.
} 
attitudinal response to the 9/11 attacks. Yet, in terms of concerns about xenophobic hostility, both high- and low-educated respondents reacted equally strongly to the attacks with lower worries about hostility. This might be interpreted as evidence for the limited potential of education to fully shield from non-economic attitude shocks.

The paper is organized as follows. The next section provides a brief summary of existing evidence on negative attitude shifts in the aftermath of $9 / 11$ in countries outside the US, with a particular focus on Germany. In Section 3 , the data and the employed empirical strategy are introduced. Section 4 details the results of the empirical application for Germany, and Section 5 concludes.

\section{Background}

\section{$2.1 \quad 9 / 11$ and Anti-Immigrant Attitudes}

Strong evidence from aggregate time trends suggests that anti-Muslim sentiments and xenophobic aggression increased considerably among the US population in the aftermath of the 9/11 attacks. The American-Arab Anti-Discrimination Committee (2003) reports over 700 incidents targeting Arab Americans or perceived as such, including several murders. Human Rights Watch (2002) and Gould and Klor (2012) refer to data from the FBI Uniform Crime Reporting Program (UCR), showing a 16 -fold increase in the reported total number of hate crimes against Muslims from 2000 to 2001.

There is also descriptive evidence that the events of 9/11 had a negative impact on attitudes toward immigration beyond US borders. In Canada, the Toronto Police Service Hate Crime Unit statistics show a 66 percent rise in hostile acts in late 2001 (Helly, 2004, p.26). Åslund and Rooth (2005) cite aggregate statistics from the Forskargruppen för Samhälls- och Informationsstudier (FSI), showing an 18-percentage-points drop in the fraction of Swedish respondents expressing positive attitudes toward immigration from 51 percent in the period June-August 2001 to 33 percent from September 11 - September 30. With respect to the German population's reaction in response to the 9/11 attacks, Brosig and Brähler (2002) describe evidence from four representative opinion surveys collected before and after $9 / 11$, in the form of repeated cross-sections. Their findings suggest a negative change in public attitudes toward certain minority groups, particularly Muslims, with the fraction of respondents who would dislike having Muslims as neighbors rising from 12 percent in June 2001 to 19 percent in April 2002. However, there is no indication that this increase in "social distance" toward Muslims translated into more negative attitudes toward the group of immigrants or foreigners as a whole, as the fraction 
of respondents expressing a distaste for foreign or guestworker neighbors remained constant at 11 percent. Furthermore, the fear of foreigners in Germany appeared to decrease rather than increase, when comparing 2002 survey responses to results from 1999 (Brosig and Brähler, 2002, p.87-88).

In summary, there are suggestions of a negative attitude shift following the 9/11 terrorist attacks in the US, as well as some suggestive indication that the attacks might have also had an impact on attitudes in European countries. However, this evidence is mainly based on aggregate time trends. To the best of my knowledge, no attempts have been made within existing literature to provide systematic empirical evidence of this relationship and directly test the causality of the effects on attitudes toward immigration. However, this might be largely due to limited data availability, since most surveys of attitudes toward immigrants are collected as cross-sectional data.

\subsection{The Moderating Role of Education}

Insofar as the 9/11 terrorist attacks have triggered negative attitudes, there is no direct evidence on whether the $9 / 11$ events had a uniform effect across the entire society or whether it varied between heterogeneous subgroups of the population.2 This study offers first exploratory evidence on the types of individuals most affected in terms of immigration-related attitudes, with a focus on individuals' educational attainment.

I draw on previous literature relating to immigration-related attitude formation to differentiate between groups who are likely at high risk of responding to a negative and intense non-economic attitude shock such as the 9/11 attacks, and those who are expected to be at relatively lower risk of changing their minds. Most studies find that education plays a key role in the perception of immigration and immigrants (e.g. Bauer et al., 2000; Scheve and Slaughter, 2001; Mayda, 2006; Dustmann and Preston, 2007; Hainmueller and Hiscox, 2007, 2010). Gang and Rivera-Batiz (1994) and Fertig and Schmidt (2011) confirm the findings of the low-educated holding relatively more negative attitudes in the German context. However, what lies at the heart of the consistently found positive relationship between educational attainment and attitudes toward immigration and immigrants is controversially debated in the economic literature. On the one hand, the fact that the highly educated hold more favorable attitudes may predominantly reflect their labor market position, which is

\footnotetext{
${ }^{2}$ The most closely related study is Cornelissen and Jirjahn (2012), who find negative 9/11-effects in terms of wage discrimination only among low-skilled Muslim employees, and not among the higher skilled Muslims. Assuming that low-skilled Muslims have low-skilled German superiors and co-workers, they attribute this finding to a moderating effect of education in xenophobic attitudes.
} 
less vulnerable to typically low-skilled immigration. However, on the other hand, it could also reflect the liberizing effect of education per se, resulting in less ethnic prejudice and greater appreciation of cultural diversity among the highly educated.

The context of the $9 / 11$ attacks in 2001 provides a quasi-experimental setting inducing an exogenous shock on individuals' attitudes toward immigrants and immigration. In the following, I will argue that this shock has been non-economic in nature and thus increased perceived cultural rather than economic threat. As will be shown in Section 4.1.1, it appears likely that the attacks may not have been perceived as associated with increased immigration inflows or changes in immigrants' skill composition or productivity. In view of 9/11 as a non-economic exogenous shock and against the background of the previous literature on attitude formation, I thus hypothesize that the attacks had a stronger impact on the attitudes of relatively lower educated than highly educated Germans. I furthermore expect a moderating role of education with respect to both individual concerns over immigration as well as worries about hostility toward foreigners.

Hence, in contrast to the previous literature, the quasi-experimental setting of the $9 / 11$ attacks allows me to go beyond the analysis of cross-sectional associations and examine within-individual variation in attitudinal reactions to the exogenous shock. In this way, I can not only isolate non-economic from economic drivers of immigration-related attitudes, but also overcome omitted variable issues that might potentially bias cross-sectional analysis.

\section{$3 \quad$ Data and Empirical Setup}

\subsection{Data}

This study examines the effects of $9 / 11$ on attitudes toward immigration among German residents. The terrorist attacks of September 11, 2001 act as an exogenous shock providing a powerful quasi-experiment. I use a large longitudinal dataset, consisting of around 20,000 individuals, which allows controlling for individual heterogeneity and underlying time trends.

The German Socio-Economic Panel (SOEP) is a nationally representative, longitudinal study of private households in Germany, conducted in annual waves starting in 1984. $5^{3}$ Respondents are interviewed throughout the year with random timing of the interviews. Although the bulk of interviews usually take place during the first half of each year, a considerable number of respondents are interviewed during the later months. Such data thus provides the unique opportunity to exploit the timing

\footnotetext{
${ }^{3}$ See Wagner et al. (2007) for a comprehensive description of this dataset.
} 
of survey interviews in 2001 to identify $9 / 11$ effects..$^{4}$

The two main dependent variables employed in this analysis measure individuals' concerns over immigration to Germany and hostility toward foreigners or minorities in Germany, on a three-point scale ranging from "not at all" to "somewhat" to "very concerned". In 2000, 32.09 percent of native German respondents were very concerned about immigration to Germany, while 21.90 percent where not at all concerned. In the same year, 31.26 percent stated a strong concern over hostility toward foreigners or minorities in Germany, with 16.55 percent not at all worried about this issue $5^{5}$ Measures of concern over general economic development and about crime in Germany are scaled in the same way as the main dependent variables.

Two subsamples are considered in the following. The first includes all individuals aged 17 or older without a so-called migration background ${ }^{6}$ who were interviewed between January 2000 and December 2001, i.e. the 2000 and 2001 SOEP waves. Individuals who took no interview in 2001 or were interviewed on the date of September 11 in 2001 are excluded from the analysis. Moreover, observations with missing information on either of the two main dependent variables are also discarded (1.58 percent of the total sample). This first sample is unbalanced and includes a total of 34,653 observations (16,663 in 2000 and 17,990 in 2001). Next, I consider a second subsample, which additionally includes the two-year period before and after the $9 / 11$ terror attacks, i.e. the waves 1999-2004. This second unbalanced sample consists of 70,799 observations.

\section{Table 1 about here}

Descriptive statistics of the two samples are presented in Table 1. Each of the samples is again split into two groups - the pre-9/11 (control) group including individuals who were interviewed in 2001 between January 1 and September 10, and the post-9/11 (treatment) group consisting of individuals surveyed between September 11 and December 31 in the year 2001. Individuals in the post-9/11 group are on average younger, report a slightly higher household income, less likely to be on maternal leave or widowed, and more likely to be single than respondents in the control group. Although it is not clear why such differences occur, it is important to control for these characteristics.

\footnotetext{
${ }^{4}$ See Berger (2010) for an example of a previous study exploiting random interview timing in the SOEP, examining the impact of the reactor accident at the Chernobyl nuclear power plant in 1986 on individual life satisfaction and environmental worries.

${ }^{5}$ Note that the correlation between the two outcome measures is rather low, the correlation coefficient amounts to 0.0981 in 2000, which justifies separate estimation models for each dependent variable instead of joint modeling.

${ }^{6}$ An individual is defined as having a migration background if the person is an immigrant to Germany or is born in Germany to at least one immigrant parents.
} 


\subsection{Empirical Strategy}

I apply a difference-in-difference approach to identify the effects of $9 / 11$ on individual attitudes of German natives toward immigration and xenophobic hostility, comparing attitude levels of pre- and post-9/11 respondents in 2001 and relating them to the same respondents' attitude levels one year prior. $A_{i t}$ denotes the level of concern over immigration (hostility toward foreigners) of individual $i$ at time $t$. Post9/11 is a dummy variable equal to one if the survey interview took place after September 11 in 2001, i.e. in the period from September 12 to December 31 in 2001, and zero otherwise. Year=2001 is a dummy representing the 2001 survey year, the year of the terror attacks, $u_{i}$ is an individual fixed effect, and $\epsilon_{i t}$ is a time-varying random error term.

$A_{i t}=\alpha+\beta_{1}$ Post9 $/ 11_{i t}+\beta_{2}(\text { Year }=2001)_{t}+\beta_{3}\left[\right.$ Post9 $\left./ 11_{i t} \times(\text { Year }=2001)_{t}\right]+u_{i}+\epsilon_{i t}$

Parameter $\beta_{3}$ is the difference-in-difference estimator that will represent the causal impact of 9/11 on those interviewed between September 12 and December 31 in 2001 (i.e. the average treatment effect on the treated), under the assumption that attitudes of the pre- and post-9/11 group would have changed identically in the absence of the terror events (common trend assumption). This parameter is identified through variation in average attitude levels between respondents who were interviewed before and after 9/11 in 2001, and the comparison of this difference with variation in average attitudes between the pre- and post-9/11 group in 2000 . $\beta_{3}$ is estimated by applying either pooled OLS with clustering at the individual level, random-effects or fixed-effects models to the above equation. In the following, I will additionally provide estimates of this approach including an extended time period of two years before and after the terror attacks, i.e. the years 1999-2003, to carefully control for underlying aggregate time trends. 


\section{Results and Discussion}

\subsection{Baseline results}

Table 2 presents first evidence of a 9/11 impact on individual attitudes toward immigration and concerns over xenophobic hostility in Germany, with estimates using OLS as well as GLS random- and fixed-effects models shown for each dependent variable. With respect to attitudes toward immigration, the coefficients on the interaction term between Post9/11 and Year=2001 are statistically significant and positive across all three models. The point estimates range between 0.129 and 0.152 , which is around 38 to 44 percent of one within-individual standard deviation in worries about immigration. This indicates that the post-9/11 treatment group experienced a substantial increase in concerns over immigration, while at the same time respondents in the pre-9/11 control group were even slightly less worried about immigration in 2001 than these same individuals reported in 2000. Interestingly, a similar pattern is observed with respect to people's concerns over hostility toward foreigners or minorities in Germany. Across all three models, the estimated coefficient on the interaction term is significant and negative, with magnitudes ranging from around 29 to 36 percent of one within standard deviation in concerns over xenophobic hostility. This implies that the 9/11 attacks did not only result in increased worries about immigration, but also a decrease in worries about xenophobic hostility in Germany. The significant and positive coefficient on Year=2001 indicates that the control group of pre-9/11 respondents instead experienced a moderate increase in such concerns from 2000 to 2001.

\section{Table 2 about here}

This first set of results demonstrate the immediate negative effects of the $9 / 11$ terror attacks in the US on public attitudes in a European country. However, an important assumption is that the attitudes of both the treatment and control group would have followed a similar path in the absence of the treatment. One means of checking this is to consider whether both groups' attitude levels followed a similar trend in the years preceding 2001 and the years after the event. Figure 1 shows that the average levels of individuals' worries about immigration and concern over xenophobic hostility follow a very similar trend for both pre- and post-9/11 groups in the two-year periods before and after 2001. However, in the year of the attacks the trend diverges for the two groups, with a noticeable increase in worries about immigration and a considerable decrease in concerns over xenophobic hostility for those interviewed post-9/11 from 2000 to 2001. This is consistent with the estimated treatment effects presented in Table 2 . 
Figure 1 about here

In a next step, I incorporate the two years before and after the attacks (survey years 1999-2003) in the empirical analysis, to control more carefully for underlying time trends. In this second set of estimations, controls for gender, age, age squared and log household income, as well as dummies for marital status, labor force status, education, federal state and interview month are added. The results of the GLS models with random and fixed effects respectively are presented in Table 3. With this full specification, the estimated coefficients on the interactions of interest (Post9/11× Year=2001) remain positive and statistically significant in the case of worries about immigration and significantly negative with respect to concerns about xenophobic hostility. In contrast, coefficients on the interaction terms between the post-9/11 treatment group and indicators for the years prior to or post-2001 appear not to be significantly different from zero. This supports the view that, controlling for the relevant covariates, the attitudes of the treatment group do not systematically differ from those of the pre-9/11 control group for reasons other than the exogenous and unanticipated 9/11 terror shock. Note that in the years prior to 2001 both groups are untreated, while both are treated in the years after 2001. We thus only expect both groups to differ in the year 2001 due to interview timings pre- or post-9/11, which appears to be confirmed by the estimation results in Table 3 . Overall, the findings fit the evidence on international spillovers based on aggregated time trends.

Table 3 about here

\subsubsection{Robustness}

Was the shift toward more negative immigration-related attitudes following the 9/11 terror attacks accompanied by shifts in other, more general types of macro attitudes? Of special interest here are people's concerns over general economic development and worries about crime in Germany. Accordingly, Table 4 explores the possibility that the $9 / 11$ attacks also had an impact on these attitudes. Rerunning random and fixed effects models in the specification of Table 3 with measures of worries about economic development and crime in Germany as dependent variables suggests no significant impact of 9/11 on these concerns. For all models in Table 4 . the coefficient on the interaction of interest $($ Post9/11 $\times$ Year=2001) is statistically insignificantly different from zero. This suggests that the effects shown in Section 4.1 are not a result of an increased public awareness of security issues or changes in other economic concerns related to immigration. Instead, it is consistent with the interpretation of $9 / 11$ representing a non-economic shock. 
Table 4 about here

\subsection{Effect Heterogeneity and the Role of Education}

Having established empirical evidence that the 9/11 terror events had significant negative effects on individual attitudes toward immigration and resulted in a decrease in worries about xenophobic hostility in Germany, I now investigate whether different types of individuals have been more or less responsive to the $9 / 11$ shock. Along with possible differential effects on individuals according to their education levels, I also examine effect heterogeneity with respect to demographic characteristics such as gender and age, as well as regional foreigner concentration. Tables 5 and 6 recalculate the random effects estimations from Table 3 for split samples by gender, age (i.e. below and above the age of 35), below and above average years of education (i.e. below and above 12 years of education) and federal states with below and above average shares of foreigners, respectively, for both main dependent variables.

As indicated by the first set of results in Table 5, men may have been slightly, however not statistically significantly, more responsive than women to the $9 / 11$ attacks in terms of worries about immigration. Similarly, younger individuals appear to have reacted more strongly than older people, but these differences are also not very substantial. Furthermore, when comparing respondents in federal states with a relatively low share of foreigners with those in states with a relatively higher share of foreigners, there appear to be no significantly different reactions to the $9 / 11$ events in terms of attitudes toward immigration. The latter finding is particularly interesting in the light of empirical evidence from previous studies employing cross-sectional analysis in the German context. For example, Fertig and Schmidt (2001) find that a lower regional foreigner concentration is associated with less favorable immigrationrelated attitudes among natives on average. However, in response to 9/11, individuals do not seem to update their attitudes toward immigration differently according to whether they reside in a region with a low- or high share of foreigners.

The previous background discussion suggests that education may moderate 9/11 effects. Indeed, the estimation results by education level show that the attacks had a larger impact on the group of relatively lower educated individuals than the highly educated. Moreover, the difference is substantial and statistically significant.7 Within the subsample of highly educated individuals, the estimated coefficient on

\footnotetext{
${ }^{7}$ I additionally estimated specifications introducing interaction effects instead of split samples by education level. Results are presented in Table A1 in the Appendix for both dependent variables. Similar estimations including interactions with respect to age, gender and regional foreigner share yield non-significant coefficients on the respective interaction terms. These results are available upon request.
} 
the interaction Post9/11 $\times$ Year=2001 is small in size and not significantly different from zero. Hence, the group of highly educated does not appear to have updated their attitudes toward immigration in the light of the $9 / 11$ events.

\section{Table 5 about here}

The second set of results in Table 6 deals with effect heterogeneity with respect to individual concerns over xenophobic hostility. Interestingly, the estimated coefficients on the interaction Post9/11 × Year=2001 are very similar to each other throughout the split samples, and the differences between males and females, young and old, residents in regions with low and high share of foreigners, and also between the low and the high-educated group are not statistically significant. Consequently, the 9/11 attacks appear to have uniformly lowered individuals' worries about xenophobic hostility across the population subgroups analyzed. In particular, there is no evidence of a moderating role of education, with both the highly and lower educated reacting equally strongly to the attacks by being less concerned about xenophobic tendencies in the German society. This result is especially striking considering the previous finding of a moderating effect with respect to peoples' attitudes toward immigration.

\section{Table 6 about here}

However, the ambiguous nature of the measure of individuals' concerns over xenophobic hostility does not allow for a straightforward interpretation of the latter results, as the survey question might in fact trigger diverse connotations. For instance, while one person might report weak concerns over xenophobic hostility due to a distaste for foreigners in Germany or a lack of empathy with them, another individual may report weak concerns due to their belief that there are no xenophobic tendencies immanent in the German society. The former would therefore reflect an opinion toward minorities or immigrants, while the latter would rather represent an opinion toward fellow German residents. Unfortunately, the different associations related to the survey question are not observable to the researcher, and might even differ according to the respondent's educational level. The result of lower concerns over xenophobic hostility in response to the $9 / 11$ events could thus either be interpreted as a shift to more negative attitudes toward immigrants and minorities, or alternatively might indicate a shift to more positive attitudes toward fellow German natives. While it is not possible to clearly distinguish between these two interpretations within this study, it is certainly not intuitive to think of a large-scale terror attack as to having resulted in expectations of decreasing xenophobic tendencies in Germany, especially given the German history of xenophobic incidents and violent 
acts against foreigners (see e.g. Krueger and Pischke, 1997). Against this background, the finding of low- and high-educated respondents reacting equally strongly to the 9/11 events with lower worries about xenophobic hostility casts some doubt on the moderating role of education in this context.

The results presented here might rather point at distorting effects due to real or perceived social desirability response bias, which is both higher for the better educated and more prevalent in the more obtrusive question on concerns over immigration. Studying such distorting effects on expressions of immigration attitudes in survey interviews, e.g. Janus (2010) finds that college graduates are more likely than respondents with a lower educational level to conceal anti-immigration views when asked directly . Stocké (2007) shows that better educated respondents of the German General Social Survey (ALLBUS) perceive stronger social desirability incentives when answering racial attitude questions than the less educated. If the survey question on xenophobic hostility is perceived as less obtrusive, especially due to its ambiguous connotation, then its responses may be more in line with individuals' "true" attitudes. In turn, this would suggest that the finding of a moderating role of education with respect to attitudes toward immigration is solely an artifact of self-presentational concerns. However, I cannot observe respondents' sensitivity to social desirability pressures within this setting, and thus the above interpretation efforts must remain of a speculative nature.

\section{Summary and Conclusion}

This study highlights that the 9/11 terror attacks in the US had a significant and negative impact on individual attitudes toward immigration and immigrants among native German residents. More specifically, it is shown that the attacks increased worries about immigration by around 38 to 44 percent of one withinindividual standard deviation, and lowered concerns over xenophobic hostility by approximately 29 to 36 percent of one within standard deviation. These effects are significant and robust.

Moreover, this analysis provides evidence for the role of educational attainment in moderating individuals' attitudinal responses to a major event such as $9 / 11$. In fact, highly educated respondents have not shown any significant change in attitudes toward immigration in the aftermath of the attacks, whereas the lower educated reacted with a considerable and significant shift to more negative immigration attitudes. However, evidence with respect to individual concerns over xenophobic hostility show a different pattern, with both low- and high-educated individuals reacting equally strongly to the $9 / 11$ attacks by lowering their concerns over xenophobic 
hostility in Germany. Despite the ambiguous character of the measure of attitudes toward xenophobic tendencies, this finding may cast some doubt on a universal moderating role of education.

Overall, this study provides the first causal evidence that the 9/11 terror attacks in the US provoked substantial changes toward more negative immigration-related attitudes within the wider German society. It shows that external non-economic shocks and other major media events may have the potential to trigger voters' cultural prejudices and frame the public debate. Mixed evidence on the moderating role of education points to the important future research agenda of examining the mechanisms behind the potential effect of education on anti-immigration and antiforeigner sentiments. Another step for further study in this context would be to probe the influence of social desirability pressures among the highly educated. 


\section{References}

American-Arab Anti-Discrimination Committee (2003). Report on Hate Crimes and Discrimination Against Arab Americans: The Post-September 11 Backlash. American-Arab Anti-Discrimination Committee Report, ADC Research Institute, Washington. Available at http://www.adc.org/PDF/hcr02.pdf.

Åslund, O. and D.-O. Rooth (2005). Shifts in Attitudes and Labor Market Discrimination: Swedish Experiences after 9-11. Journal of Population Economics 18(4), 603-629.

Bauer, T. K., M. Lofstrom, and K. F. Zimmermann (2000). Immigration Policy, Assimilation of Immigrants and Natives' Sentiments Towards Immigrants: Evidence from 12 OECD-Countries. Swedish Economic Policy Review 7(2), 11-53.

Berger, E. M. (2010). The Chernobyl Disaster, Concern about the Environment, and Life Satisfaction. Kyklos 63(1), 1-8.

Braakmann, N. (2009). The Impact of September 11th, 2001 on the Employment Prospects of Arabs and Muslims in the German Labor Market. Journal of Economics and Statistics (Jahrbücher für Nationalökonomie und Statistik) 299(1), $2-21$.

Braakmann, N. (2010). Islamistic Terror and the Labour Market Prospects of Arab Men in England: Does a Country's Direct Involvement Matter? Scottish Journal of Political Economy 57(4), 430-454.

Brosig, B. and E. Brähler (2002). Die Angst vor dem Terror - Daten aus deutschen Repräsentativerhebungen vor und nach dem 11. September (The Fear of Terror - Data from German Representative Surveys Before and After September 11). Journal für Konflikt-und Gewaltforschung (Journal of Conflict and Violence Research) 4(2), 77-94.

Card, D., C. Dustmann, and I. Preston (2012). Immigration, Wages, and Compositional Amenities. Journal of the European Economic Association 10(1), 78-119.

Ceobanu, A. M. and X. Escandell (2010). Comparative Analyses of Public Attitudes Toward Immigrants and Immigration Using Multinational Survey Data: A Review of Theories and Research. Annual Review of Sociology 36(1), 309-328.

Cornelissen, T. and U. Jirjahn (2012). September 11th and the Earnings of Muslims in Germany - The Moderating Role of Education and Firm Size. Journal of Economic Behavior and Organization 81(2), 490-504. 
Dávila, A. and M. T. Mora (2005). Changes in the Earnings of Arab Men in the US between 2000 and 2002. Journal of Population Economics 18(4), 587-601.

Dustmann, C. and I. P. Preston (2007). Racial and Economic Factors in Attitudes to Immigration. The B.E. Journal of Economic Analysis 6 Policy 7(1), Article 62.

Fertig, M. and C. M. Schmidt (2001). First-and Second-Generation Migrants in Germany-What Do We Know and What Do People Think? In R. Rotte and P. Stein (Eds.), Migration Policy and the Economy: International Experiences, Number 286, pp. 179-218. Neuried: Ars et unitas.

Fertig, M. and C. M. Schmidt (2011). Attitudes towards Foreigners and Jews in Germany: Identifying the Determinants of Xenophobia in a large Opinion Survey. Review of Economics of the Household 9(1), 99-128.

Gang, I. N. and F. L. Rivera-Batiz (1994). Unemployment and Attitudes Towards Foreigners in Germany, pp. 121-54. Physica Verlag.

Goel, D. (2010). Perceptions of Immigrants in Australia after 9/11. Economic Record 86(275), 596-608.

Gould, E. D. and E. F. Klor (2012). The Long-Run Effect of 9/11: Terrorism, Backlash, and the Assimilation of Muslim Immigrants in the West. CEPR Discussion Paper 8797.

Hainmueller, J. and M. J. Hiscox (2007). Educated Preferences: Explaining Attitudes Toward Immigration in Europe. International Organization 61(02), 399-442.

Hainmueller, J. and M. J. Hiscox (2010). Attitudes toward Highly Skilled and Lowskilled Immigration: Evidence from a Survey Experiment. American Political Science Review 104(1), 61-84.

Helly, D. (2004). Are Muslims discriminated against in Canada since September 2001? Canadian Ethnic Studies 36(4), 24-45.

Human Rights Watch (2002). "We are not the Enemy": Hate Crimes against Arabs, Muslims, and Those Perceived to be Arab or Muslim after September 11. Human Rights Watch 6, available at http://www.hrw.org/sites/default/files/reports/usa1102.pdf.

Janus, A. L. (2010). The Influence of Social Desirability Pressures on Expressed Immigration Attitudes. Social Science Quarterly 91(4), 928-946. 
Kaushal, N., R. Kaestner, and C. Reimers (2007). Labor market effects of September 11th on Arab and Muslim residents of the United States. Journal of Human Resources 42(2), 275-308.

Krueger, A. B. and J.-S. Pischke (1997). A Statistical Analysis of Crime Against Foreigners in Unified Germany. Journal of Human Resources 32, 182-209.

Mayda, A. M. (2006). Who is Against Immigration? A Cross-Country Investigation of Individual Attitudes Toward Immigrants. The Review of Economics and Statistics 88(3), 510-530.

Metcalfe, R., N. Powdthavee, and P. Dolan (2011). Destruction and Distress: Using a Quasi-Experiment to Show the Effects of the September 11 Attacks on Mental Well-Being in the United Kingdom. The Economic Journal 121(550), 81-103.

Orrenius, P. M. and M. Zavodny (2006). Did 9/11 Worsen the Job Prospects of Hispanic Immigrants? Unpublished manuscript, Federal Reserve Bank of Dallas Research Department.

Rabby, F. and W. M. Rodgers (2011). Post 9-11 U.S. Muslim Labor Market Outcomes. Atlantic Economic Journal 39(3), 273-289.

Scheve, K. F. and M. J. Slaughter (2001). Labor Market Competition and Individual Preferences over Immigration Policy. The Review of Economics and Statistics 83(1), 133-145.

Shannon, M. (2012). Did the September 11th Attacks affect the Canadian Labour Market? Economics Letters 115(1), 91-93.

Stocké, V. (2007). Determinants and Consequences of Survey Respondents' Social Desirability Beliefs about Racial Attitudes. Methodology: European Journal of Research Methods for the Behavioral and Social Sciences 3(3), 125-138.

Wagner, G. G., J. R. Frick, and J. Schupp (2007). The German Socio-Economic Panel Study (SOEP) - Scope, Evolution and Enhancements. Schmollers Jahrbuch 127(1), 139-169. 
Table 1: Descriptive Statistics

\begin{tabular}{|c|c|c|c|c|c|c|}
\hline & \multicolumn{3}{|c|}{ Sample 2000-2001 } & \multicolumn{3}{|c|}{ Sample 1999-2003 } \\
\hline & All & Pre-9/11 & Post-9/11 & All & Pre-9/11 & Post-9/11 \\
\hline$N$ & 34,653 & 34,046 & 607 & 70,799 & 69,730 & 1,069 \\
\hline Worries immigration & $\begin{array}{l}2.050 \\
(0.726)\end{array}$ & $\begin{array}{l}2.050 \\
(0.727)\end{array}$ & $\begin{array}{l}2.044 \\
(0.710)\end{array}$ & $\begin{array}{l}2.072 \\
(0.722)\end{array}$ & $\begin{array}{l}2.072 \\
(0.722)\end{array}$ & $\begin{array}{l}2.028^{*} \\
(0.744)\end{array}$ \\
\hline Worries hostility toward foreigners & $\begin{array}{l}2.181 \\
(0.679)\end{array}$ & $\begin{array}{l}2.181 \\
(0.680)\end{array}$ & $\begin{array}{l}2.163 \\
(0.641)\end{array}$ & $\begin{array}{l}2.128 \\
(0.666)\end{array}$ & $\begin{array}{l}2.128 \\
(0.667)\end{array}$ & $\begin{array}{l}2.112 \\
(0.655)\end{array}$ \\
\hline Male & 0.477 & 0.477 & 0.499 & 0.478 & 0.478 & $0.511 *$ \\
\hline Age & 46.546 & 46.577 & $44.817^{*}$ & 47.237 & 47.270 & 45.065 \\
\hline Ln(net household income) & 8.321 & 8.320 & $8.412^{*}$ & 8.057 & 8.056 & $8.148^{*}$ \\
\hline Lower than secondary degree & 0.031 & 0.030 & 0.040 & 0.026 & 0.026 & $0.039 *$ \\
\hline Secondary degree & 0.801 & 0.801 & 0.784 & 0.803 & 0.804 & $0.775^{*}$ \\
\hline Tertiary degree & 0.168 & 0.168 & 0.176 & 0.171 & 0.170 & 0.186 \\
\hline Full-time employed & 0.423 & 0.423 & 0.433 & 0.421 & 0.420 & 0.431 \\
\hline Unemployed & 0.099 & 0.100 & 0.091 & 0.101 & 0.101 & 0.102 \\
\hline Other Employment & 0.205 & 0.204 & $0.252^{*}$ & 0.202 & 0.201 & $0.247^{*}$ \\
\hline Retired & 0.220 & 0.221 & 0.191 & 0.232 & 0.232 & $0.186^{*}$ \\
\hline Maternity leave & 0.020 & 0.020 & $0.008^{*}$ & 0.018 & 0.018 & $0.007^{*}$ \\
\hline In education & 0.032 & 0.032 & 0.025 & 0.028 & 0.028 & 0.027 \\
\hline Married & 0.636 & 0.637 & 0.608 & 0.639 & 0.639 & $0.609 *$ \\
\hline Single & 0.230 & 0.228 & $0.292^{*}$ & 0.223 & 0.222 & $0.280^{*}$ \\
\hline Divorced & 0.070 & 0.070 & 0.059 & 0.072 & 0.072 & 0.071 \\
\hline Widowed & 0.064 & 0.065 & $0.041^{*}$ & 0.066 & 0.067 & $0.040^{*}$ \\
\hline
\end{tabular}

Notes: Attitude measures (worries) take a value of $1=$ not concerned at all, $2=$ somewhat concerned, and $3=$ very concerned. An individual is assigned to the pre- $9 / 11$ group if they were interviewed between January 1, 2001 and September 10, 2001 and to the post-9/11 group if the 2001 interview took place between 12 September and 31 December that year. * Statistically different from pre-9/11 mean at the 5 percent confidence level.

Table 2: Worries about Immigration (Worries about Hostility toward Foreigners) and the 9/11 Attacks - Unbalanced Panel, SOEP 2000 - 2001

\begin{tabular}{|c|c|c|c|c|c|c|}
\hline & \multicolumn{3}{|c|}{ Worries about Immigration } & \multicolumn{3}{|c|}{ Worries about Hostility } \\
\hline & OLS & $\mathrm{RE}$ & $\mathrm{FE}$ & OLS & $\mathrm{RE}$ & $\mathrm{FE}$ \\
\hline Post-9/11 & $\begin{array}{c}-0.073^{*} \\
(0.042)\end{array}$ & $\begin{array}{l}-0.082^{*} \\
(0.043)\end{array}$ & & $\begin{array}{l}0.051 \\
(0.034)\end{array}$ & $\begin{array}{l}0.042 \\
(0.040)\end{array}$ & \\
\hline Year $=2001$ & $\begin{array}{l}-0.099^{* * *} \\
(0.006)\end{array}$ & $\begin{array}{l}-0.097^{* * *} \\
(0.005)\end{array}$ & $\begin{array}{l}-0.094^{* * *} \\
(0.005)\end{array}$ & $\begin{array}{l}0.069^{* * *} \\
(0.006)\end{array}$ & $\begin{array}{l}0.071^{* * *} \\
(0.006)\end{array}$ & $\begin{array}{l}0.074^{* * *} \\
(0.006)\end{array}$ \\
\hline Year $=2001 \times$ Post- $9 / 11$ & $\begin{array}{l}0.129^{* * *} \\
(0.043)\end{array}$ & $\begin{array}{l}0.141^{* * *} \\
(0.041)\end{array}$ & $\begin{array}{l}0.152^{* * *} \\
(0.042)\end{array}$ & $\begin{array}{l}-0.131^{* * *} \\
(0.045)\end{array}$ & $\begin{array}{l}-0.119^{* * *} \\
(0.044)\end{array}$ & $\begin{array}{l}-0.103^{* *} \\
(0.045)\end{array}$ \\
\hline Constant & $\begin{array}{l}2.102^{* * *} \\
(0.006)\end{array}$ & $\begin{array}{l}2.099^{* * *} \\
(0.006)\end{array}$ & $\begin{array}{l}2.098^{* * *} \\
(0.004)\end{array}$ & $\begin{array}{l}2.146^{* * *} \\
(0.005)\end{array}$ & $\begin{array}{l}2.143^{* * *} \\
(0.005)\end{array}$ & $\begin{array}{l}2.144^{* * *} \\
(0.004)\end{array}$ \\
\hline$N$ & 34,653 & 34,653 & 34,653 & 34,653 & 34,653 & 34,653 \\
\hline
\end{tabular}

Source: SOEP 2000-2001, own calculations.

Notes: Worries about immigration and worries about hostility toward foreigners take a value of $1=$ not concerned at all, $2=$ somewhat concerned, and $3=$ very concerned. Post- $9 / 11$ takes a value of 1 for both years (i.e. 2000 and 2001) if the individual was interviewed between January 1, 2001 and September 10, 2001 and 0 between 12 September 2001 and 31 December 2001. Base year $=2000$. Standard errors are in parentheses and, in the OLS case, robust to the clustering by individual identification. ${ }^{*} p<0.10,{ }^{* *} p<0.05,{ }^{* * *} p<0.01$. 
Figure 1: Trends in Worries about Immigration (Worries about Hostility toward Foreigners) Before and After the 9/11 Attacks, SOEP 1999 - 2003
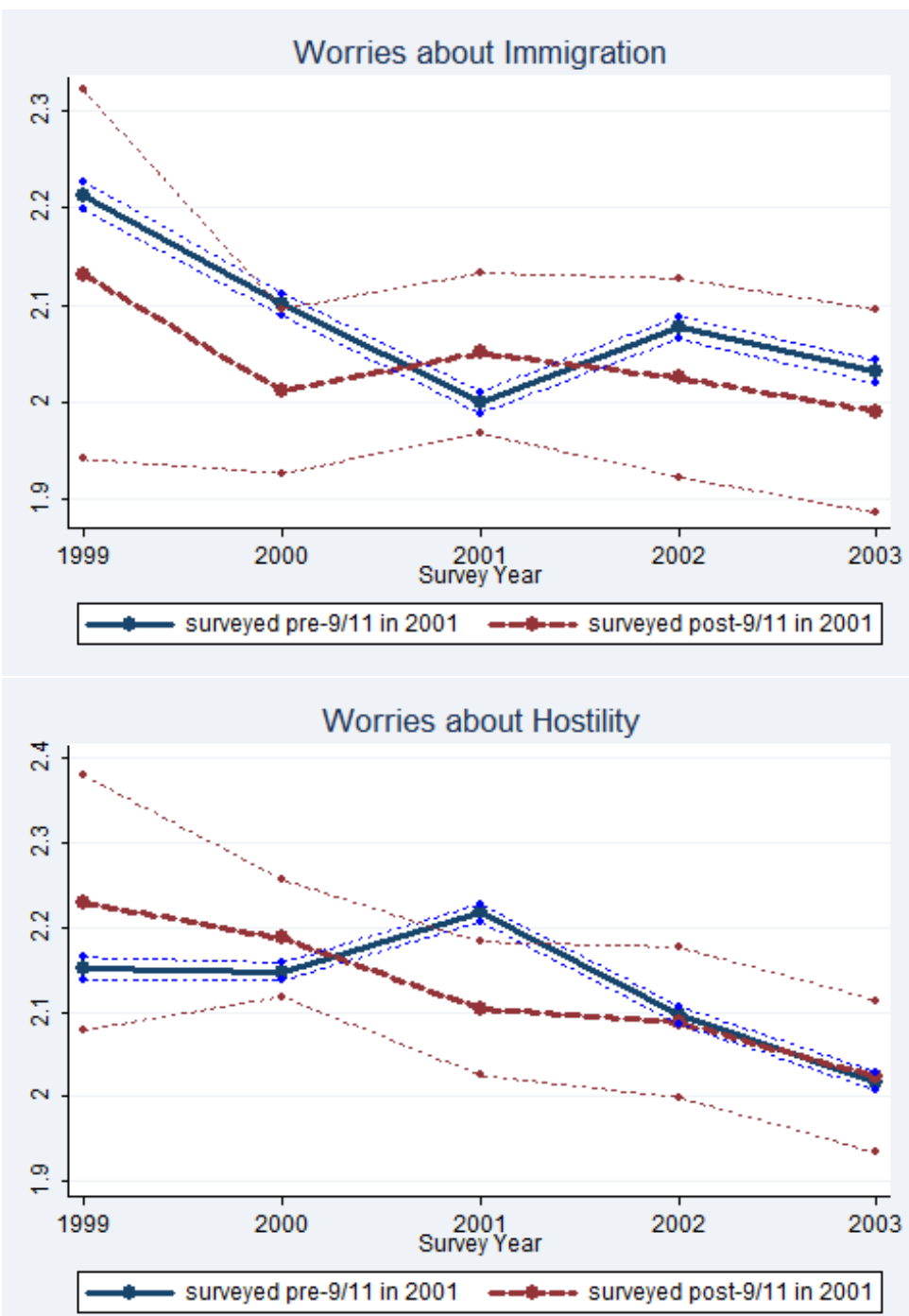

Source: SOEP 1999-2003, own calculations.

Note: 2001 is the year of the 9/11 attacks. Thin dashed lines represent the $95 \%$-confidence interval. 
Table 3: Worries about Immigration (Worries about Hostility toward Foreigners) and the 9/11 Attacks - Multiple time periods, SOEP 1999 - 2003

\begin{tabular}{|c|c|c|c|c|}
\hline & \multicolumn{2}{|c|}{ Worries about Immigration } & \multicolumn{2}{|c|}{ Worries about Hostility } \\
\hline & $\mathrm{RE}$ & $\mathrm{FE}$ & $\mathrm{RE}$ & $\mathrm{FE}$ \\
\hline Post-9/11 & $\begin{array}{l}-0.033 \\
(0.076)\end{array}$ & & $\begin{array}{l}0.044 \\
(0.075)\end{array}$ & \\
\hline Year $=2000$ & $\begin{array}{l}-0.087^{* * *} \\
(0.007)\end{array}$ & $\begin{array}{l}-0.080^{* * *} \\
(0.012)\end{array}$ & $\begin{array}{l}-0.012^{*} \\
(0.007)\end{array}$ & $\begin{array}{l}-0.001 \\
(0.012)\end{array}$ \\
\hline Year $=2001$ & $\begin{array}{l}-0.190^{* * *} \\
(0.007)\end{array}$ & $\begin{array}{l}-0.182^{* * *} \\
(0.020)\end{array}$ & $\begin{array}{l}0.077^{* * *} \\
(0.007)\end{array}$ & $\begin{array}{l}0.098^{* * *} \\
(0.020)\end{array}$ \\
\hline Year $=2002$ & $\begin{array}{l}-0.148^{* * *} \\
(0.008)\end{array}$ & $\begin{array}{l}-0.112^{* * *} \\
(0.029)\end{array}$ & $\begin{array}{l}-0.039^{* * *} \\
(0.008)\end{array}$ & $\begin{array}{l}-0.011 \\
(0.030)\end{array}$ \\
\hline Year $=2003$ & $\begin{array}{l}-0.195^{* * *} \\
(0.008)\end{array}$ & $\begin{array}{l}-0.158^{* * *} \\
(0.038)\end{array}$ & $\begin{array}{l}-0.115^{* * *} \\
(0.008)\end{array}$ & $\begin{array}{l}-0.079^{* *} \\
(0.039)\end{array}$ \\
\hline Year $=2000 \times$ Post $-9 / 11$ & $\begin{array}{l}-0.034 \\
(0.077)\end{array}$ & $\begin{array}{l}-0.047 \\
(0.080)\end{array}$ & $\begin{array}{l}-0.032 \\
(0.078)\end{array}$ & $\begin{array}{l}0.002 \\
(0.082)\end{array}$ \\
\hline Year $=2001 \times$ Post $-9 / 11$ & $\begin{array}{l}0.170^{* *} \\
(0.079)\end{array}$ & $\begin{array}{l}0.171^{* * *} \\
(0.081)\end{array}$ & $\begin{array}{l}-0.308^{* * *} \\
(0.080)\end{array}$ & $\begin{array}{l}-0.259^{* * *} \\
(0.083)\end{array}$ \\
\hline Year $=2002 \times$ Post-9/11 & $\begin{array}{l}-0.002 \\
(0.078)\end{array}$ & $\begin{array}{l}-0.007 \\
(0.081)\end{array}$ & $\begin{array}{l}-0.082 \\
(0.079)\end{array}$ & $\begin{array}{l}-0.056 \\
(0.083)\end{array}$ \\
\hline Year $=2003 \times$ Post-9/11 & $\begin{array}{l}-0.002 \\
(0.079)\end{array}$ & $\begin{array}{l}-0.005 \\
(0.081)\end{array}$ & $\begin{array}{l}-0.076 \\
(0.080)\end{array}$ & $\begin{array}{l}-0.061 \\
(0.083)\end{array}$ \\
\hline Male & $\begin{array}{l}0.029^{* * *} \\
(0.009)\end{array}$ & & $\begin{array}{l}-0.107^{* * *} \\
(0.008)\end{array}$ & \\
\hline Age & $\begin{array}{l}0.005^{* * *} \\
(0.002)\end{array}$ & & $\begin{array}{l}0.009^{* * *} \\
(0.001)\end{array}$ & \\
\hline Age-squared/100 & $\begin{array}{l}-0.003^{*} \\
(0.002)\end{array}$ & & $\begin{array}{l}-0.011^{* * *} \\
(0.001)\end{array}$ & \\
\hline Secondary degree & $\begin{array}{l}0.027 \\
(0.020)\end{array}$ & $\begin{array}{l}0.013 \\
(0.029)\end{array}$ & $\begin{array}{l}-0.025 \\
(0.019)\end{array}$ & $\begin{array}{l}0.009 \\
(0.030)\end{array}$ \\
\hline Tertiary degree & $\begin{array}{l}-0.298^{* * *} \\
(0.023)\end{array}$ & $\begin{array}{l}0.018 \\
(0.041)\end{array}$ & $\begin{array}{l}0.038^{*} \\
(0.022)\end{array}$ & $\begin{array}{l}-0.042 \\
(0.042)\end{array}$ \\
\hline Unemployed & $\begin{array}{l}-0.016 \\
(0.010)\end{array}$ & $\begin{array}{l}-0.004 \\
(0.013)\end{array}$ & $\begin{array}{l}-0.030^{* * *} \\
(0.010)\end{array}$ & $\begin{array}{l}-0.016 \\
(0.013)\end{array}$ \\
\hline Other employment & $\begin{array}{l}-0.038^{* * *} \\
(0.009)\end{array}$ & $\begin{array}{l}-0.015 \\
(0.011)\end{array}$ & $\begin{array}{l}0.010 \\
(0.008)\end{array}$ & $\begin{array}{l}0.000 \\
(0.011)\end{array}$ \\
\hline Retired & $\begin{array}{l}-0.015 \\
(0.013)\end{array}$ & $\begin{array}{l}-0.042^{* *} \\
(0.019)\end{array}$ & $\begin{array}{l}-0.002 \\
(0.013)\end{array}$ & $\begin{array}{l}0.003 \\
(0.019)\end{array}$ \\
\hline Maternity leave & $\begin{array}{l}-0.015 \\
(0.019)\end{array}$ & $\begin{array}{l}0.006 \\
(0.022)\end{array}$ & $\begin{array}{l}0.018 \\
(0.019)\end{array}$ & $\begin{array}{l}0.002 \\
(0.022)\end{array}$ \\
\hline In education & $\begin{array}{l}-0.119^{* * *} \\
(0.018)\end{array}$ & $\begin{array}{c}-0.037^{*} \\
(0.021)\end{array}$ & $\begin{array}{l}-0.013 \\
(0.018)\end{array}$ & $\begin{array}{l}-0.062^{* * *} \\
(0.022)\end{array}$ \\
\hline Single & $\begin{array}{l}-0.100^{* * *} \\
(0.013)\end{array}$ & $\begin{array}{c}-0.047^{*} \\
(0.025)\end{array}$ & $\begin{array}{l}-0.030^{* *} \\
(0.012)\end{array}$ & $\begin{array}{l}0.013 \\
(0.026)\end{array}$ \\
\hline Divorced & $\begin{array}{l}-0.023 \\
(0.014)\end{array}$ & $\begin{array}{l}0.017 \\
(0.024)\end{array}$ & $\begin{array}{l}-0.037^{* * *} \\
(0.013)\end{array}$ & $\begin{array}{l}-0.027 \\
(0.025)\end{array}$ \\
\hline Widowed & $\begin{array}{l}-0.088^{* * *} \\
(0.018)\end{array}$ & $\begin{array}{l}-0.086^{* *} \\
(0.039)\end{array}$ & $\begin{array}{l}-0.060^{* * *} \\
(0.016)\end{array}$ & $\begin{array}{l}-0.004 \\
(0.040)\end{array}$ \\
\hline Ln(net household income) & $\begin{array}{l}-0.047^{* * *} \\
(0.007)\end{array}$ & $\begin{array}{l}-0.012 \\
(0.010)\end{array}$ & $\begin{array}{l}0.006 \\
(0.007)\end{array}$ & $\begin{array}{l}0.002 \\
(0.010)\end{array}$ \\
\hline Constant & $\begin{array}{l}2.504^{* * *} \\
(0.081)\end{array}$ & $\begin{array}{l}2.817^{* * *} \\
(0.353)\end{array}$ & $\begin{array}{l}2.156^{* * *} \\
(0.076)\end{array}$ & $\begin{array}{l}2.501^{* * *} \\
(0.362)\end{array}$ \\
\hline$N$ & 70,799 & 70,799 & 70,799 & 70,799 \\
\hline
\end{tabular}


Table 4: Robustness Check: Other Worries and the 9/11 Attacks - Multiple time periods, SOEP 1999 - 2003

\begin{tabular}{|c|c|c|c|c|}
\hline & \multicolumn{2}{|c|}{$\begin{array}{c}\text { Worries about } \\
\text { Economic Development }\end{array}$} & \multicolumn{2}{|c|}{$\begin{array}{l}\text { Worries about } \\
\text { Crime in Germany }\end{array}$} \\
\hline & $\mathrm{RE}$ & $\mathrm{FE}$ & $\mathrm{RE}$ & $\mathrm{FE}$ \\
\hline Post-9/11 & $\begin{array}{l}0.009 \\
(0.068)\end{array}$ & & $\begin{array}{l}-0.025 \\
(0.068)\end{array}$ & \\
\hline Year $=2000$ & $\begin{array}{l}-0.070^{* * *} \\
(0.007)\end{array}$ & $\begin{array}{l}-0.067^{* * *} \\
(0.011)\end{array}$ & $\begin{array}{l}-0.021^{* * *} \\
(0.006)\end{array}$ & $\begin{array}{l}-0.015 \\
(0.011)\end{array}$ \\
\hline Year $=2001$ & $\begin{array}{l}-0.099^{* * *} \\
(0.006)\end{array}$ & $\begin{array}{l}-0.099^{* * *} \\
(0.019)\end{array}$ & $\begin{array}{l}-0.063^{* * *} \\
(0.006)\end{array}$ & $\begin{array}{l}-0.051^{* * *} \\
(0.018)\end{array}$ \\
\hline Year $=2002$ & $\begin{array}{l}0.093^{* * *} \\
(0.007)\end{array}$ & $\begin{array}{l}0.120^{* * *} \\
(0.028)\end{array}$ & $\begin{array}{l}-0.110^{* * *} \\
(0.007)\end{array}$ & $\begin{array}{l}-0.069^{* *} \\
(0.027)\end{array}$ \\
\hline Year $=2003$ & $\begin{array}{l}0.359^{* * *} \\
(0.008)\end{array}$ & $\begin{array}{l}0.385^{* * *} \\
(0.036)\end{array}$ & $\begin{array}{l}-0.170^{* * *} \\
(0.007)\end{array}$ & $\begin{array}{l}-0.123^{* * *} \\
(0.035)\end{array}$ \\
\hline Year $=2000 \times$ Post-9/11 & $\begin{array}{l}-0.103 \\
(0.072)\end{array}$ & $\begin{array}{l}-0.100 \\
(0.076)\end{array}$ & $\begin{array}{l}0.008 \\
(0.070)\end{array}$ & $\begin{array}{l}-0.010 \\
(0.073)\end{array}$ \\
\hline Year $=2001 \times$ Post-9/11 & $\begin{array}{l}0.092 \\
(0.073)\end{array}$ & $\begin{array}{l}0.104 \\
(0.078)\end{array}$ & $\begin{array}{l}0.014 \\
(0.071)\end{array}$ & $\begin{array}{l}0.010 \\
(0.075)\end{array}$ \\
\hline Year $=2002 \times$ Post-9/11 & $\begin{array}{l}-0.009 \\
(0.073)\end{array}$ & $\begin{array}{l}-0.015 \\
(0.077)\end{array}$ & $\begin{array}{l}-0.001 \\
(0.071)\end{array}$ & $\begin{array}{l}-0.025 \\
(0.074)\end{array}$ \\
\hline Year $=2003 \times$ Post-9/11 & $\begin{array}{l}0.026 \\
(0.074)\end{array}$ & $\begin{array}{l}0.027 \\
(0.078)\end{array}$ & $\begin{array}{l}0.031 \\
(0.072)\end{array}$ & $\begin{array}{l}0.009 \\
(0.074)\end{array}$ \\
\hline Constant & $\begin{array}{l}2.132^{* * *} \\
(0.067)\end{array}$ & $\begin{array}{l}2.303^{* * *} \\
(0.336)\end{array}$ & $\begin{array}{l}2.577^{* * *} \\
(0.070)\end{array}$ & $\begin{array}{l}2.298^{* * *} \\
(0.323)\end{array}$ \\
\hline$N$ & 70,693 & 70,693 & 70,703 & 70,703 \\
\hline
\end{tabular}




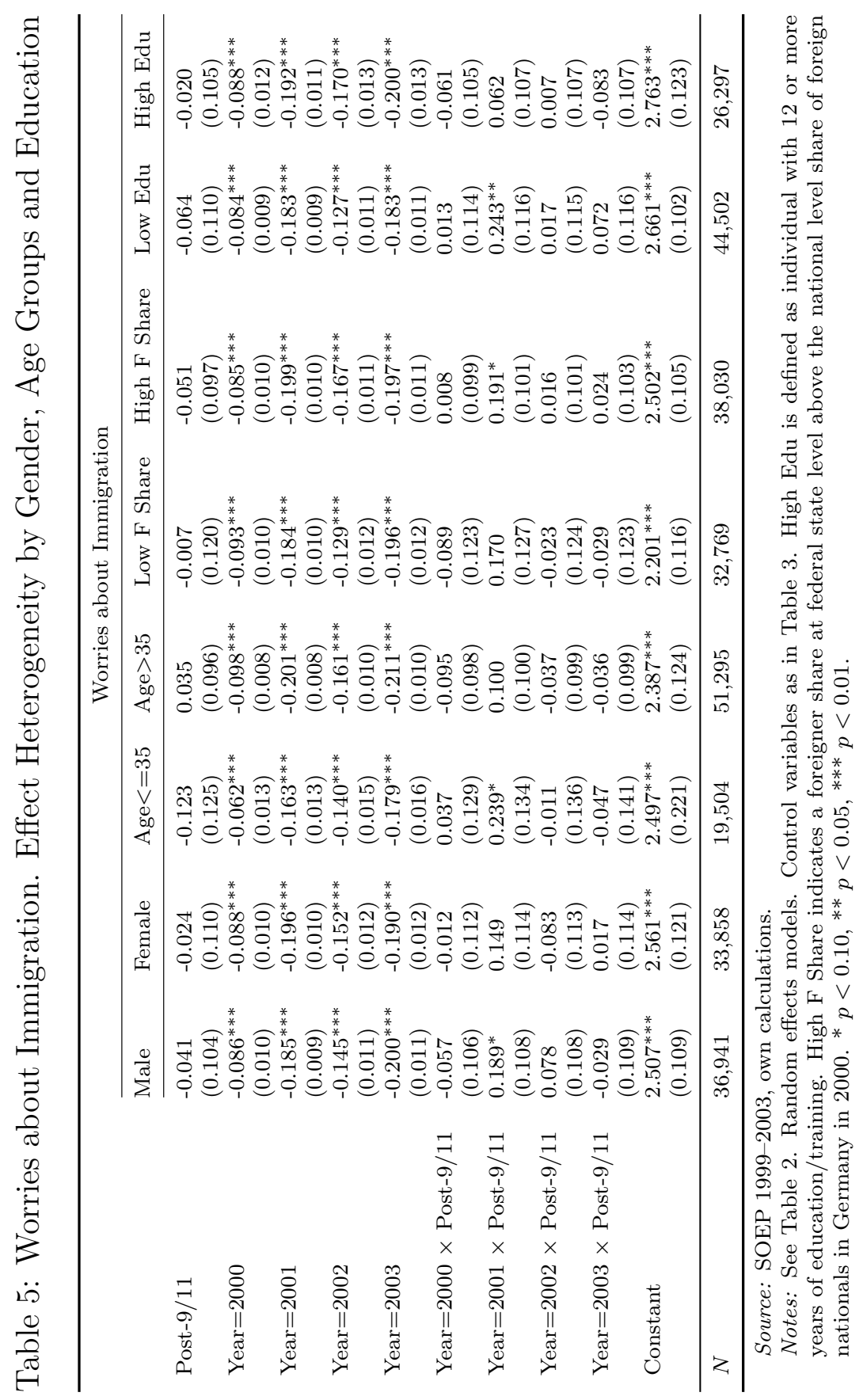




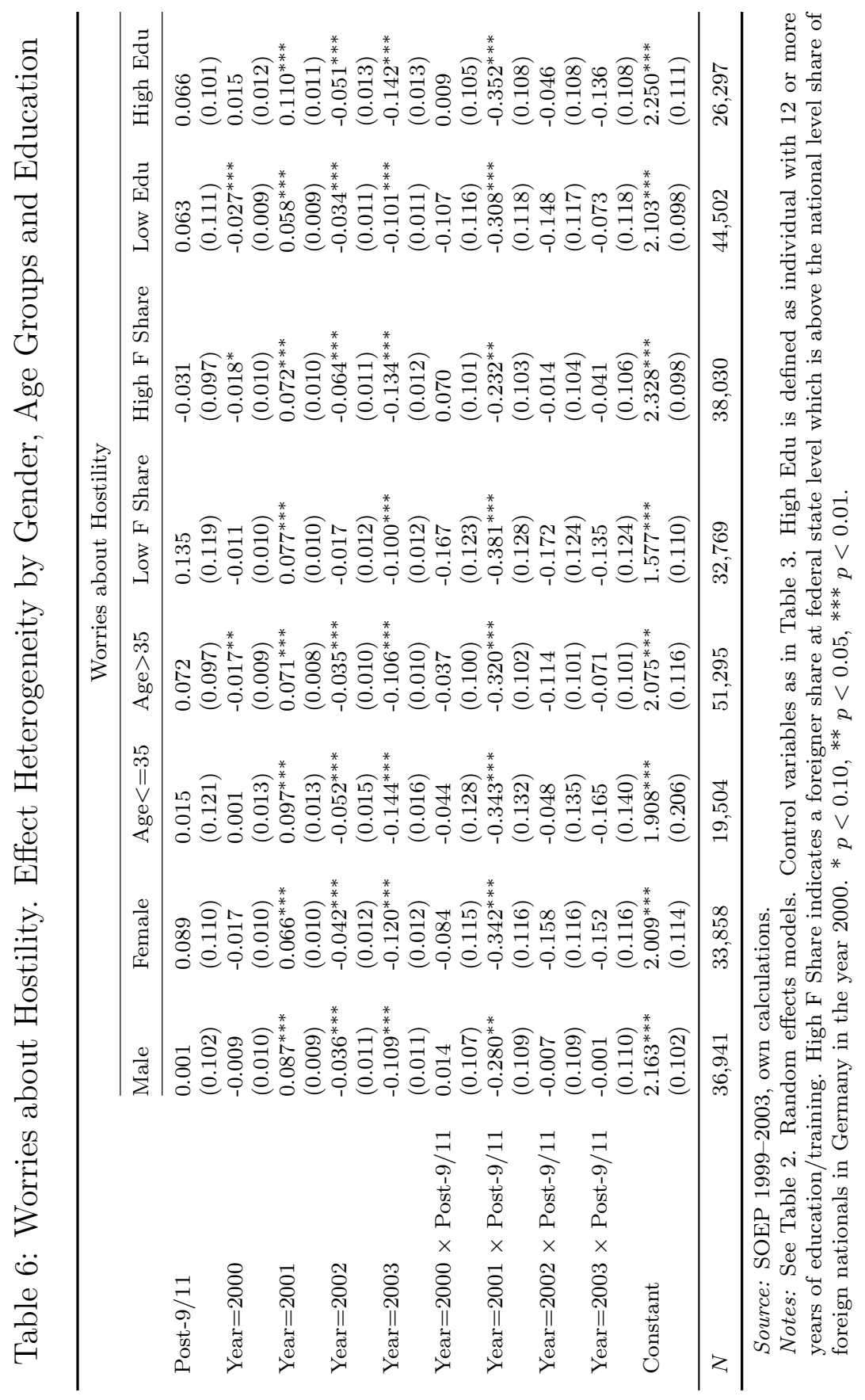




\section{Appendix}

Table A1: Three-Way Interaction - 9/11 Effects and the Moderating Role of Education

\begin{tabular}{|c|c|c|}
\hline & $\begin{array}{l}\text { Worries about } \\
\text { Immigration }\end{array}$ & $\begin{array}{l}\text { Worries about } \\
\text { Hostility }\end{array}$ \\
\hline Year $=2000$ & $\begin{array}{l}-0.066^{* * *} \\
(0.009)\end{array}$ & $\begin{array}{l}-0.033^{* * *} \\
(0.009)\end{array}$ \\
\hline Year $=2001$ & $\begin{array}{l}-0.167^{* * *} \\
(0.009)\end{array}$ & $\begin{array}{l}0.052^{* * *} \\
(0.009)\end{array}$ \\
\hline Year $=2002$ & $\begin{array}{l}-0.115^{* * *} \\
(0.010)\end{array}$ & $\begin{array}{l}-0.043^{* * *} \\
(0.010)\end{array}$ \\
\hline Year $=2003$ & $\begin{array}{l}-0.173^{* * *} \\
(0.010)\end{array}$ & $\begin{array}{l}-0.110^{* * *} \\
(0.010)\end{array}$ \\
\hline High-Edu & $\begin{array}{l}-0.185^{* * *} \\
(0.013)\end{array}$ & $\begin{array}{l}0.051^{* * *} \\
(0.013)\end{array}$ \\
\hline Year $=2000 \times$ High-Edu & $\begin{array}{l}-0.028^{*} \\
(0.015)\end{array}$ & $\begin{array}{l}0.047^{* * *} \\
(0.015)\end{array}$ \\
\hline Year $=2001 \times$ High-Edu & $\begin{array}{l}-0.029^{* *} \\
(0.015)\end{array}$ & $\begin{array}{l}0.058^{* * *} \\
(0.015)\end{array}$ \\
\hline Year $=2002 \times$ High-Edu & $\begin{array}{l}-0.062^{* * *} \\
(0.015)\end{array}$ & $\begin{array}{l}-0.003 \\
(0.015)\end{array}$ \\
\hline Year $=2003 \times$ High-Edu & $\begin{array}{l}-0.031^{* *} \\
(0.015)\end{array}$ & $\begin{array}{l}-0.028^{*} \\
(0.015)\end{array}$ \\
\hline Post-9/11 $\times$ High-Edu & $\begin{array}{l}0.011 \\
(0.149)\end{array}$ & $\begin{array}{l}0.030 \\
(0.148)\end{array}$ \\
\hline Post-9/11 & $\begin{array}{l}-0.056 \\
(0.106)\end{array}$ & $\begin{array}{l}0.033 \\
(0.105)\end{array}$ \\
\hline Year $=2000 \times$ Post $-9 / 11$ & $\begin{array}{l}0.026 \\
(0.110)\end{array}$ & $\begin{array}{l}-0.079 \\
(0.111)\end{array}$ \\
\hline Year $=2001 \times$ Post $-9 / 11$ & $\begin{array}{l}0.306^{* * *} \\
(0.110)\end{array}$ & $\begin{array}{l}-0.288^{* * *} \\
(0.111)\end{array}$ \\
\hline Year $=2002 \times$ Post $-9 / 11$ & $\begin{array}{l}0.022 \\
(0.110)\end{array}$ & $\begin{array}{l}-0.115 \\
(0.112)\end{array}$ \\
\hline Year $=2003 \times$ Post-9/11 & $\begin{array}{l}0.078 \\
(0.111)\end{array}$ & $\begin{array}{l}-0.044 \\
(0.113)\end{array}$ \\
\hline Year $=2000 \times$ Post-9 $/ 11 \times$ High-Edu & $\begin{array}{l}-0.094 \\
(0.156)\end{array}$ & $\begin{array}{l}0.093 \\
(0.157)\end{array}$ \\
\hline Year $=2001 \times$ Post-9 $/ 11 \times$ High-Edu & $\begin{array}{l}-0.278^{*} \\
(0.154)\end{array}$ & $\begin{array}{l}-0.056 \\
(0.156)\end{array}$ \\
\hline Year $=2002 \times$ Post-9 $/ 11 \times$ High-Edu & $\begin{array}{l}-0.010 \\
(0.158)\end{array}$ & $\begin{array}{l}0.075 \\
(0.160)\end{array}$ \\
\hline Year $=2003 \times$ Post-9 $/ 11 \times$ High-Edu & $\begin{array}{l}-0.148 \\
(0.159) \\
\end{array}$ & $\begin{array}{l}-0.083 \\
(0.161) \\
\end{array}$ \\
\hline$N$ & 70,799 & 70,799 \\
\hline
\end{tabular}

Source: SOEP 1999-2003, own calculations.

Notes: See Table 2 Random effects models. Control variables as in Table 3 High-Edu is defined as individual with 12 or more years of education/training. ${ }^{*} p<0.10,{ }^{* *} p<0.05,{ }^{* * *} p<0.01$. 